\title{
The Power of Language in and Following Moments of Trauma: An Analysis of A Stolen Life
}

- Morgan Aprill, Ball State University

n June of 1991, a young Jaycee Dugard
was taken off the street of her hometown neighborhood and forced into sexual slavery. She was only eleven years old. For years, Jaycee Dugard lived in the backyard of Phillip and Nancy Garrido's property, forced to spend her days in a system of tents and small buildings somehow concealed from the neighbors in a California town and raped repeatedly by Phillip. Her book explains how Phillip exploited and abused her, kept her locked up naked in a room alone in order to break down her will, used words to beat down her spirit, and slowly integrated her into his and his wife's lives as a part of a highly dysfunctional family. Jaycee's memoir details her strange day-to-day captivity as she gradually gained permission to leave the house and even use a computer. Many would

\section{Abstract:}

This paper examines the memoir of Jaycee

Dugard, a woman who was kidnapped as a child and kept as a sexual slave for much of her life. Her work demonstrates how language is blocked in times of trauma but also how writing is an essential tool for victims to use to sort through their experiences. This paper also looks at the ways in which her captor kept her under his control through physical and verbal threat to show how language can help keep someone imprisoned. By looking more closely at stories like Jaycee's, people can better understand the experience of the victim and the tactics of the abuser, and people can more effectively help victims of sexual slavery and abuse.

\section{KEY WORDS:}

Child sexual slavery, sexual slavery, memoir, trauma, Jaycee Dugard wonder why Jaycee had not tried to escape sooner as her allowances increased, but by analyzing her thoughts and narration, we can better understand the debilitating brainwashing and psychological abuse that kept her from seeking an escape sooner.

The narratives that come from survivors about their experiences are essential tools in helping victims in the future, understanding the tactics of victimizers and how their abuse works on victims, and putting an end to sexual slavery and abuse of children. Detailing her captivity for eighteen years, Jaycee's book is full of insights into the perceived experience of an abused child, the ease with which her captors kept and abused her, and how cathartic the writing process is for victims of trauma. It is important to think about how we can look at trauma and the literature created through and surrounding it in discussions about some of the world's most awful subjects. Jaycee's experience is one that should never happen to any child. Yet millions of children, the overwhelming majority being females, are sexually abused and still kept as slaves today. 


\section{SLAVERY Today}

As much as we would like to deny it, the number of abducted children who are forced into slavery is immense. According to a recent fact sheet from the International Labour Organization, almost 21 million people are living in slavery across the globe, with 11.4 million of these victims being women or girls and 9.5 million being men and boys. Four and a half million of these are forced into sexual slavery, meaning millions of children are still being exploited daily. A report in the Huffington Post from 2013 stated that two children are sold for sex every minute across the globe (Harden). Any child in slavery is one too many, and it should be everyone's concern that these numbers are erased as more children are brought home safely and those responsible for their exploitation are put behind bars. Another essential part of this course of rescue and reunion is the therapy and processing for the victims.

Many therapists realize the necessity of writing in dealing with victims of PTSD, as the memories and their effects can be very confusing. Authors Crystal Park and Carol Blumberg note this finding, explaining that "asking people to write on consecutive days about a previously experienced traumatic event ... is associated with better subsequent health as reflected by a number of different health indicators" (597-598). They then attempt in their article to look at what research has been done on "the potential underlying mechanism of meaning-making" by survivors of trauma through writing their experiences (Park and Blumberg 598). Indeed, many literary scholars of trauma theory have worked to look at how the psychological effects of trauma can cause trouble for a survivor who wants to narrate his or her experience. This, of course, has a scientific neurological basis, but it is theorists like Cathy Caruth who have helped us realize just how delicate the connection between language, memory, and mental health can be.

Trauma is personal and many times indescribable and unrecountable. James Berger puts it well in his article: "Trauma theory is another such discourse of the unrepresentable, of the event or object that destabilizes language and demands a vocabulary and syntax in some sense incommensurable with what went before" (573). Berger's article outlines the work of Caruth's book Trauma: Explorations in Memory, as well as work by other literary trauma theorists. In her book, Caruth explains that trauma writing is a recounting of "a history that literally has no place, neither in the past, in which it was not fully experienced, nor in the present, in which its precise images and enactments are not fully understood" (353). She quotes Schreiber Weitz who explains how difficult it is to study the events of people who, for them, never began or ended due to the imprinting and time displacements involved in trauma: "What do we do? Do we not talk about it? ... To speak is impossible, and not to speak is impossible" (qtd. in Caruth 354). In other words, he asks what is to be done to help those suffering from experiences that are unspeakable yet must be spoken about. Those who write about their traumatic experiences are taking control of times when they felt completely helpless, which is a way of bringing about mental processing and healing. Elissa Marder also looks at the history of trauma theory, specifically Shoshana Felman and Dori Laub's influential book Testimony. Marder explains that Felman and her colleague Laub importantly stated that "even though we do not 'recover' from our traumatic past, nor can we 'cure' it, 'overcome' it, or even fully understand it, we can and we must listen to it and survive it by listening to its effects as they are transmitted to us through the voices of its witnesses and survivors" (Marder 4). This is exactly what we must do with the stories of survivors of child sexual slavery such as Jaycee Dugard.

In the introduction of her book, Jaycee explains the two reasons she decided to write her book. She says those reasons are "that Phillip Garrido believes no one should find out what he did to 
an eleven-year-old girl" and that she wishes "that it will be of help to someone going through, hopefully not similar conditions, but someone facing a difficult situation of their own" (Dugard ix). She outlines the initial days of her captivity in detail and provides snapshots into what she can remember of the years she spent as Phillip's slave. Though she does not overtly say it, we can see how she also uses the book to help her sort through what has happened to her. Jaycee writes in present tense when she writes about the events she shares, but she follows many of these with present-day commentary, sometimes saying how she is feeling in that moment as she is writing the memoir. Though she has moments where she says she does not know if she can go on, she does. Through her memoir, we get a glimpse into the mind of a child who is suffering from abuse and manipulation.

The brain of a child is not as developed as an adult's, and to grow up in an environment of constant fear must have had an impact on her development in some way. This article will analyze how language is used within Jaycee's memoir-how she perceives her experience now with the help of authoring her trauma, how language was used by her captors to keep her enslaved, and how she processes her experience during her time in captivity. All of these are examples of how powerful words are as they empower and disempower Jaycee throughout her book. To understand how this could be, let us look at some scientific research into the brain and how it reacts to and processes prolonged trauma.

\section{The SCIEnCE Behind STRESS}

Research has shown that certain chemicals flood the body when the brain is presented with life-threatening situations. You are probably familiar with the brain's release of adrenaline when we find ourselves in thrilling situations like in a fast-moving roller coaster or running from something we find frightening. The brain also releases other chemicals that change our neurological chemistry in times of prolonged fear or stress. According to an article by Elizabeth Hopper and José Hidalgo, there are "neurological and neuroanatomical changes that are associated with exposure to traumatic stress. The perception of threat leads to a biologically-based fear response, causing the body to enter an instinctive survival mode with specific neurobiological changes" (201). Hopper and Hidalgo go on to explain in detail just what kinds of hormones are released during the human body's response to stress and threats, including descriptions of how cognitive thinking becomes impaired:

There is decreased activity in the cortical system, particularly within the frontal cortex. With this decrease in frontal lobe activity, cognitive functions such as abstract thinking, problem-solving, planning, and impulse control are temporarily inhibited. Therefore ... people may experience impaired ability in effective planning and problem-solving. (203)

Similar descriptions of the brain's functioning under stress can be found in Sandra Bloom's article "Trauma Theory Abbreviated." Bloom explains that our ability to think clearly is impaired by stress and that long-term effects can be found in victims in regards to how they think: "An intolerance of mistakes, denial of personal difficulties, anger as a problem-solving strategy, hypervigilance, and absolutistic thinking are other problematic thought patterns that have been identified" (5). There are also issues that arise in memory. How we process new memories and recall old ones is affected under stress. According to Bloom, "There are actually two different memory systems in the brain - one for normal learning and remembering that is based on words and another that is largely nonverbal" (5). When we are under high levels of stress, we lose some ability to 
access our verbal memory and, in this way, "Problems may arise later [for victims of trauma] because the memory of the events that occurred under severe stress are not put into words and are not remembered in the normal way we remember other things" (Bloom 6). This is why, during flashbacks of traumatic experiences, victims often act out the previous event as their memory has been imprinted differently than normal, and sometimes their only way of accessing it, due to repression and other wonders of the brain, is through their physical memory. This is why it is especially hard for victims of trauma to put words to their past experiences. As Bloom explains, "For healing to occur, we know that people often need to put the experience into a narrative, give it words, and share it with themselves and others. Words allow us to put things into a time sequence-past, present, future.... Words allow us to put the past more safely in the past where it belongs" (7). This makes Dugard's book that much more important as her authorship allows her to process and put words to the events she remembers from her childhood though she may not have complete verbal memory of them. Children are especially vulnerable to exploitation and psychological confusion when it comes to stress and abuse situations.

Children who are traumatized can have undeveloped coping skills, self-relation to others, or a sense of self (Bloom 10). Trauma interferes with normal development of senses of right and wrong and social skills. Children who grow up in these environments can become accustomed to the unhealthiness and then be unable to have fulfilling relationships with others because of this. Often, they are the kids who cause trouble as they try to sort out their trauma in ways that often go against social convention (Bloom 10). Bloom also explains that this can be due to a child's increased exposure to the endorphins released from stress in his or her home, leading to an addiction to stress and a need to disrupt calm. Additionally, "Children who suffer disrupted attachments may suffer from damage to all of their developmental systems, including their brains, and we are particularly ill-suited to having the people we are attached to also be the people who are violating us" (Bloom 2). This explains a lot of what Jaycee struggles with throughout her time in captivity. She is confused, torn, and ultimately psychologically enslaved because of the way that the Garridos show her comfort and provide for her but also horribly abuse her. The brain of a child becomes damaged, making it harder and harder for them to see a way out of the situation or understand what a healthy familial relationship would actually look like. It is in the memoir that we can see into the mind of not only Jaycee but also into that of her abusers and how this noxious situation ate away at her being and further incapacitated her. For example, she mentions how she became trained to not show her feelings or to not ask too many questions because of how guilty and shameful Phillip would make her feel for speaking up. He would talk and talk and explain just how wrong she was. He would also provide her with conflicting comfort such as hugs and presents. By analyzing Phillip's actions and words, we gain further knowledge into the psychological nature of abuse.

\section{The TACTICS OF THE AbUSER}

This book also gives us a way to understand how abusers manipulate their victims. Phillip uses depravation, conflicting treatment, and — most interestingly — his words to degrade Jaycee into what she becomes. In fact, he maintains most of his manipulation through his conversations with her, which made her feel guilty and hopeless. Slowly, she gains more privileges but never truly has a normal life while in captivity, though she seems to feel compassion for her captors. The Garridos even create a fake family of sorts, further entrapping Jaycee by providing something, though in a very twisted manner, that she so longs for and misses. It is important to understand just how 
the abuser works to help us comprehend Jaycee's actions and emotions and to help others like her in the future. The deprivation of simple freedom of movement is just one of the ways the Garridos mold Jaycee and how she was slowly broken down.

We see in Jaycee's narrations of her start in captivity of how she lost track of time and dayssomething that worked to break her will. Soon after being locked up in the music room, Jaycee writes that she begins to wonder how long she has been there, though she feels like she has been there forever: "This room is getting hot when I wake up the next morning; at least I think it is morning. There is really no way to tell ... [sic] How much time has passed?” (Dugard 25). Being stuck in this room, chained up, she admits that she began to depend on Phillip for everything: "He became my entire world" (Dugard 26). In addition to suffering from sensory deprivation that could easily make someone start to go crazy, she also was kept in handcuffs for a good amount of time before Phillip would let her be in her cell without being further incapacitated: "He says he has to put handcuffs on me, but that they have fur on them so they won't hurt too much. I shake my head no and say that I won't try to get away. He says he has to because he doesn't trust me yet" (Dugard 21). Suffering in a hot room with no food, water, or toilet and not being able to use her hands, she admits she looked forward to him visiting her: "I depended on him.... He was my only source of amusement. I craved human contact so much by then that I actually looked forward to him coming to see me; it felt like he was bestowing a gift to me ... [sic] his presence" (26). This is a common practice in grooming someone for slavery. It is a form of torture to remove necessities like a place to go to the bathroom or a source of water or amusement from someone. Jaycee writes of how she survived having only a bucket to relieve herself, which Phillip would dump in the backyard after it had already needed to be dumped for quite a while. Slowly, she gained privileges like a TV, video games, even magazines and toys, but she still remained confined to the buildings in the back lot of the Garridos' property until late into her captivity; she eventually became so beaten down by Phillip's treatment that she was allowed outside of the house and still never dared speak up to anyone.

One of the most sickening ways Phillip abused and manipulated Jaycee was through his portrayals of shame and caring between his episodes of sexual assault on her. One of the first times we see this odd contradiction of comforting the person to whom you are causing pain is when she is first at the Garridos' house. When Phillip first captures Jaycee, he forces her to take a shower with him and asks her to touch his genitals. She complies, but soon after she is lying on the bathroom floor wrapped in a towel. She has just been taken from her family and been forced to do something very confusing to her. Crying because of his odd and confusing behavior, she is then presented with conflicting treatment as "the man takes [her] in his arms and offers comfort" (Dugard 19). She explains that she saw little choice and was just a scared child: "I do not want comfort from this awful man, but there is no one else here and I reluctantly lean into what comfort he gives.... Now I feel like a rabbit being comforted by a lion. I am so scared” (Dugard 19). It is difficult and heartbreaking to read this child's story and her emotions, but we can see here how horribly wrenching it is for a child to have to navigate her abuser being her only comfort and provider. This continues throughout the memoir.

One of the most gut-wrenchingly vivid scenes in the book comes early on with Jaycee's narration of Phillip's first rape of her in the small room he is keeping her. We can see the way he calculated his actions with her, thinking if he explained what he was about to do, then it would not be so bad for her-that if he asked her if she was okay afterwards, then it would be enough to make up for how he would be sexually abusing her for the following years. Her narration goes right back 
into the terrified, confused mind of the young girl she was when this first began: "He lies on top of me. He is so heavy. I can't stop crying... Why is he doing this? Is this normal?” (Dugard 31). The rest of the rape is described by her in what way she can understand, which is hardly at all. But immediately afterwards he asked her if she was okay: "In my mind I am screaming NO I AM NOT OKAY ... [sic] GET OFF OF ME! Why are you doing this? What does it mean?" (Dugard 32). We see he does this a lot after he rapes her, another incident coming on page 54: "He takes me in his arms and says it's okay, that he is done... He won't bother me like this for a while. I am so scared I don't know what to think. I want to believe him." Phillip mixed this abuse in with his poor caretaking of Jaycee, making her more and more vulnerable, manipulated, and confused. She also says that she would wish for the good man to come back during the times he raped her: "Everything will be okay I tell myself. He will be the nice person soon" (Dugard 54). Phillip combined this caring with a false sense of familial relationships that further entrapped Jaycee as the years went on.

As a child, Jaycee was extra vulnerable to the manipulation of an adult who would act like her father, especially when that child had always felt rejected by her fathers in the past. Jaycee explains she never knew her biological father and that her step-father seemed to not care for her much. It is easy to understand why she is so eager to grasp onto the moments when Phillip seemed to act like a caring father to her. He provided her with toys, became her sole source of comfort and affection, and maintained her physical needs like hunger (albeit extremely poorly). But after being locked up and unable to move during her first weeks in captivity, she is eager to accept whatever he gives her, quickly learning that it is best to take what little she can get rather than risk having nothing again. Slowly, the Garridos became like a small family, as Jaycee gave birth to Phillip's children and his wife Nancy became a regular visitor to Jaycee's prison in the backyard. Phillip used his words also to urge Jaycee that trying to escape would be futile and that outside there were many people that would hurt her, as if she was not being hurt enough by him. But Jaycee writes, "He always took care of everything. He always had an answer for everything. If I ever questioned him, yes, he would listen, but then he would tell me why I was wrong and why only his way would work" (Dugard 143). His use of language was just as powerful a tool to enslave her as was the abuse and deprivation.

The language he used kept her entrapped and also made her believe she was part of a family. In one of her chapter reflections, Jaycee explains, "Phillip's verbal abuse was very effective. Although I would have liked some direct answers to my questions, I learned to not question too much because the answer I got would be lengthy and in the end make me forget the question in the first place" (Dugard 106). His words scared her about the outside world and his deprivation of her education; she felt as if she was still a little girl even when she was the mother to two children. She felt like she would never make it outside the Garrido's home. She stayed with them out of fear for her ability to provide for her children. As her captivity went on, Nancy would become the person the children saw as their mother, making Jaycee's isolation and the false family façade more complete. Jaycee would not be allowed to tell the children the truth and was forced to go by a different name. This was a further extension of how she had been forbidden by Phillip from writing her name in a journal she had once kept for one of her many pet cats. After she created the journal, she felt very proud of it and showed it to Phillip: "He preached to me for I think an hour about how I really didn't want to write my name, and how dangerous that could be if anyone else ever read it.... So I tore out the corners with my name" (Dugard 79). Her confusion about how Phillip acted toward her continues to be something that she explores throughout the memoir. In a 
journal entry she wrote in 1998 while in captivity, she writes: "I tell myself he is not touching me in a sexual way; it is more a fatherly way now. Not that I would know what that is like" (Dugard 169). She had voiced this confusion about the affection he showed her earlier in the memoir as well: "He gives me hugs sometimes and makes me feel loved. But am I really?"(Dugard 73). Of course we know that he did not truly love her and that he is actually an evil man, but the feelings of family are powerful tactics slavers use to make their slaves even more loyal and dependent.

Indeed, Jaycee notes her feelings of utter dependence on and faux familial ties with the Garridos: "I feel I am bound to these people - my captors - by invisible bonds instead of constant handcuffs" (Dugard 130). Orlando Patterson, in his book Slavery and Social Death, describes how the system of fictive kinship is an integral part of slavery. Since slavery's inception, slaves have been referred to as "sons" or "daughters" and treated almost as family (Patterson 62-63). But those relations had a clear difference between those of actual adoption and what Meyer Fortes calls "quasi-filial" relationships of the slave and the master (qtd. in Patterson 63). Jaycee's actions near the end of her time in captivity further show her utter reliance on the Garridos as she worries even in the police office that she will somehow ruin Phillip's plan of escape. Throughout the book, Jaycee felt as if she had to keep her feelings and concerns to herself in order to keep Phillip and Nancy from getting upset. She still feels, even with police in front of her, that she must minimize the anger of her captors by keeping herself quiet. There are scenes in the book which appear very familial, as when the Garridos, along with Jaycee and her children, sit around the television eating fast food, or when Jaycee and Nancy go and get their nails done and go shopping. Jaycee sometimes seems confused about the nature of the relationship, but her fear is always constant. After years of hiding and playing the role of Allissa, she shakily writes her name on a piece of paper at the police department, and the process of reclaiming her life through language and writing begins.

\section{JAYCEE'S USE OF LANGUAGE}

After narrating her memories of being given a kitten and then it being taken away for the first time by Phillip, Jaycee shows her first complete acknowledgment of her pain and struggle to author her experience. On page 42 she states, "It hurts to write about this part. This has turned out to be a very hard book to write. Part of me does not want to continue. To reenter the state of mind I was at that age is difficult and twists my insides." She ends this short reflection by finally deciding she will continue, though the difficulty is overwhelming to her. This glimpse into her thought process is one of many that we get in this memoir, which has a wealth of ways we can see into the experience of the traumatized sorting through their own trauma through language. Her writing comes in three forms: her narration of events during her captivity as if they were happening in real time, her many reflections on these events as she works through her memories in her own timeline of events, and the snapshots into actual words from her past through journal entries, which show the manipulation and the experience that is not often so vivid for us.

Most of the memoir is written in present tense. As she works through what she remembers of her time enslaved by the Garridos, she takes herself and the reader back into the mindset of the young girl who was trying so hard to survive. Many times in the book, she says she was just doing what she had to in order to survive. She acknowledges many times that her reactions to situations can seem difficult for readers outside of the situation to understand. Why did she not constantly fight to escape? Why did she not take every chance she could to make it difficult for the Garridos to enslave her? A lot of this has to do with the treatment she received from Phillip when she was first captured. A lot of this also has to do with the treatment she continued to receive as she was 
emotionally, verbally, and physically abused. Some of this also has to do with her age when she was captured. Being eleven and being kidnapped and abused leaves one extremely helpless. Her schooling was stopped, and she had little ability to control her day-to-day life. By writing her story in present tense, she steps back into those moments when she was a scared and confused little girl and reclaims them. She relives them, and we get to watch as this process occurs. Many times, however, she must stop and take breaks to reflect on what she has been writing. Moments occur when things become too real and perhaps seem to be happening all over again to her. As theorists and scientists have explained, the memory of someone who has suffered prolonged stress can become blurred into a constant reality that never truly leaves. It is beautiful, then, that Jaycee allows us to see her therapeutic process of meaning-making and processing so vividly.

As stated before, Jaycee breaks up her reliving of her time in captivity with reflections. On page 110, after narrating the birth of her first child, Jaycee says, "How do you get through things you don't want to? You just do." This attitude of perseverance at whatever cost is essential to the portrait that Jaycee paints. We see a young girl holding onto hope that she will someday see her mother again and escape, as well as the reflections of a woman looking back at these experiences. Hope and the inner strength to persevere through horrible situations become the core of the self we see in our narrator. She speaks of how hard the process is for her: "This has turned out to be a very hard book to write, ... this is something I have worked hard to put behind me and to write about it in such detail years later is difficult. To get inside my head and relive all this stuff that happened back then is terribly hard for me ... [sic] I want to go on and I will finish it" (Dugard 42). Pages later, she describes the first time Phillip took her on what he would call a run, which were hours and hours of sexual abuse that he subjected Jaycee to as he was high on drugs. These were the worst moments of her life, and she notes that, as she writes, she finds herself sabotaging her process: "I just noticed I was trying to distract myself from writing this part.... My mind knows that what comes next is not easy for me. I am finding ways to avoid it" (49). What follows is a vivid description of the horrible things he would subject her to, including brutal rape in which he would call her by derogatory names. She writes, "I want to be somewhere else, but I am here and I must not panic" (53-54). In her reflections, she explains how he told her she was helping him not hurt other girls, how if she slacked off he would threaten to sell her, how "he would cry after he was done fucking me and beg my forgiveness" (57). Her reflections explain how confused this would make her, and how she now realizes how awful and selfish of a man he really is.

Shortly after this episode, Jaycee tells us about the first cat that the Garridos allowed her to have after complaining about how lonely she was. But it was not long before the cat became an object of shaming for Jaycee. She states how she "[began] to feel guilty for asking for her in the first place" (41). This is just one of many ways that Phillip shamed Jaycee, including in the previous page, how Phillip would explain to her that she was "helping him with his sex problem .... I think that sounds really weird, but I also don't want him to do what he is doing to me to someone else" (40). Philip always found a way to make sure Jaycee felt guilty and in the wrong for anything that happened while she was his slave. She explains the strength of his manipulation but also how she still felt anger deep down. She now can look back at things and make more sense of them. Phillip Garrido kept her imprisoned in the mind of a confused 11-year-old girl even as she grew up. Her journals, which begin on page 165, let us see into her mind as she lives through these things. She often talks about her feelings of not being in control of her life and her longing for her mother. Jaycee writes about trying desperately to actually squash her longings to escape out of fear for her children. What is most beautiful is how she can continue to remain optimistic, telling 
herself she has things to be thankful for and writing affirmations in her journals to cope. Her strength shines through in her journals and her reflections as she explains how she has moved on.

\section{Conclusion}

To understand the healing power of writing one's trauma, one needs simply to look the beautiful work that Jaycee Dugard, the young girl imprisoned for years and now mother of two, wrote. Words hold so much meaning even though they are seemingly arbitrary collections of sounds we humans have put together. Talk to any literary theorist, and you will definitely learn that words are so much more. Read the work of any survivor of trauma, and you will see the power of words. During traumatic situations, our bodies react in ways that promote our survival but that can limit our brain functioning. This can lead to events that become timeless, constantly there but also impossible to name. This paper has worked to analyze the real therapeutic process of making meaning of a traumatic event by writing. Jaycee Dugard is living a free and private life with her two children and is the founder of an organization aimed at helping families dealing with reunification after abductions. Her story is inspiring and important, as it provides theorists and therapists with many ways of looking at the processing of trauma by a survivor through language. It is also important because, by sharing her story, Jaycee helps put a voice to the millions of children suffering in sexual slavery still today. The human brain is a remarkable thing that can dream and make meaning. It can contemplate the meaning of the words it uses to make meaning as well. Even while still in captivity, Jaycee showed how writing aided her and how she saw the power of words: "So many people do not listen to their soul. I know it's just a word, but that's how we have learned to communicate - with words and through behavior. It's only human to use words to describe what can never be touched" (171). Indeed, through her words, we can see more clearly what is impossible to understand, to touch, or to know - the individual experience of a sufferer of trauma. 


\section{Works Cited}

Berger, James. “Trauma and Literary Theory." Contemporary Literature 38.3 (1997): 562-582.

Web. 27 Nov. 2014.

Bloom, Sandra L. “Trauma Theory Abbreviated." From the Family Action Plan: A Coordinated Community Response to Family Violence (1999): 1-17. Web. 30 Dec. 2014.

Caruth, Cathy. Trauma: Explorations in Memory. Baltimore: The John Hopkins University Press, 1995. PDF. 4 Jan. 2015.

Dugard, Jaycee. A Stolen Life: A Memoir. New York: Simon \& Schuster Paperbacks, 2011. Print.

Harden, Nathan. "Eight Facts You Didn't Know About Child Sex Trafficking." Huff Post. TheHuffingtonPost.com, Inc., 11 Nov. 2013. Web. 4 Feb. 2015.

Hopper, Elizabeth and José Hidalgo. "Invisible Chains: Psychological Coercion of Human Trafficking Victims.” International Human Rights Law Review 1.1 (2006): 185-209. Web. 13 Oct. 2014.

"ILO Global Estimate of Forced Labour: Results and Methodology." Fact sheet. International Labour Organization. Geneva, Switzerland. 2012. Web. 4 Feb. 2015.

Marder, Elissa. “Trauma and Literary Studies: Some 'Enabling Questions.” Reading On : A Journal of Theory and Criticism 1.1 (2006): no. pg. Web. 27 Dec. 2014.

Park, Crystal L., and Carol Joyce Blumberg. "Disclosing Trauma Through Writing: Testing the Meaning-Making Hypothesis.” Cognitive Therapy and Research 26.5 (2002): 597-616. Web. 28 Nov. 2014.

Patterson, Orlando. Slavery and Social Death: A Comparative Study. Cambridge: Harvard University Press, 1982. PDF. 19 Aug. 2014. 